\title{
KASHIN PRINCES IN 60-80S OF THE XIV CENTURY
}

(C) 2017

\author{
Abukov Sergey Navilievich, candidate of historical sciences, \\ senior lecturer of Historiography, Source Studies, Archeology and Methods of History Teaching Department \\ Donetsk National University (Donetsk, Donetsk People's Republic)
}

Abstract. In the following paper the author researches the significance of Kashin as an important centre of the Tver Principality during the reign of Grand prince Vasily Mikhailovich and the confrontation between Moscow and Tver, Kashin unstable position of the princes, caused by the struggle of parties among the local ruling elite, caught between the two centers of power. As a result, the part of the elite continued to focus on Tver, while the other gave preference to Moscow. The latter position prevailed, which led to the refusal of the Prince of Kashin from the treaty with Mikhail and his involvement in the campaign against Tver in 1375. Special attention is paid to the growth of local separatism, the fate of the Kashin Principality under the treaty of 1375, securing its secession from the supreme power of Tver, as well as the short period of its formal independence and the circumstances of its return to Tver in 1382.

The influence of the Kashin princes' kinship ties, especially the marriage of Kashin prince Mikhail Vasilievich and the Moscow princess Vasilisa Semenovna, is also analyzed, the reasons, circumstances and significance of this marriage in the light of Moscow-Tver relations in the 60-80s of the XIV century in the general context of conjugal unions of the two leading principalities of North-Eastern Rus.

Keywords: Vasily Mikhailovich; Mikhail Vasilyevich; Vasily Mikhailovich (II); Mikhail Alexandrovich; Mariya Alexandrovna; Semyon the Proud; Dmitry Donskoy; Kashin; Moscow; Tver; Prince; marriage; kinship; conflict; XIV century.

УДК $9(\mathrm{c}) 16$

$$
\begin{aligned}
& \text { «ТЕРСКИЙ ОСТРОГ, ТЕРСКИЙ РЕДУТ, ТЕРКИ?..» } \\
& \text { (ЕЩЁ РАЗ К ВОПРОСУ О РОЛИ ТЕРСКОГО ГОРОДА } \\
& \text { В ИСТОРИИ СЕВЕРО-ВОСТОЧНОГО КАВКАЗА ХУІ-ХУІ ВЕКОВ) }
\end{aligned}
$$

(C) 2017

Гарунова Нина Нурмагомедовна, доктор исторических наук, профессор кафедры истории России с древнейших времен до конца XIX в. Дагестанский государственный университет (2. Махачкала, Российская Федерация)

Суздальцева Ирина Анатольевна, кандидат исторических наук, доцент кафедры истории России Дагестанский государственный педагогический университет (2. Махачкала, Российская Федерация)

Галимова Лилия Надиповна, доктор исторических наук,

профессор кафедры гуманитарных и социальных дисциплин

Ульяновский институт гражданской авиаџии имени Главного маршала авиаџии Б.П. Бугаева (2. Ульяновск, Российская Федераџия)

Аннотация. В данной статье рассматривается история исчезнувшего русского поселения-крепости, которое относится к периоду XVI-XVIII вв. В более ранних источниках город называли Терским редутом, Терским острогом, иногда встречается более короткое название - Терки. Позднее стали использовать название Терский город, для обозначения города и крепости вблизи устья Терека, недалеко от не существующей ныне речки Тюменки. В современный период это территория левобережья Старого Терека к северо-востоку от города Кизляр Республики Дагестан.

Подвергнуты критике попытки отождествления истории двух крепостей: Трехстенного городка и Терки, а также их роли на начальном этапе в истории формирования русского населения Дагестана. Охарактеризовано влияние процесса переоформления казачества в военно-служивое сословие на историческое развитие областей Северо-Восточного Кавказа. Уделено внимание такому вопросу, как наличие различных версий названия города, по месторасположению которого расходятся мнения исследователей.

Сделан акцент на роли Терского города как южного форпоста российской государственности, проводника ее кавказской политики на Северо-Восточном Кавказе.

Проведен анализ проблемы, позволивший рассмотреть интеграцию провинциальных регионов периферии в систему Российского государства на юге страны, а также проанализировано развитие опорных пунктов по распространению влияния России в XVI-XVII вв.

Ключевые слова: крепость; поселение; Терки; Терский город; Терский острог, казаки; политика; Россия; Северо-Восточный Кавказ; торговля; воевода; купцы; Кремль; граница; слобода; редут; острог; устье Терека; артиллерия; гарнизон; наводнение; торговые ряды; башни; двор; служилые люди; корабль; оружие.

Одним из значимых городов-крепостей низовий Терека был Терский город, который представлял собой весьма сложный социально-культурный организм, сложившийся в специфических геополитиче- ских условиях. Выполняя пограничную службу, он являлся форпостом восточной политики Русского государства, центром дипломатических связей с кавказскими феодальными владетелями, Грузией, Ира- 
ном, а позже с Индией и другими восточными государствами. Однако в вопросе месторасположения до сих пор нет необходимой ясности и единой точки зрения, так как, во-первых, имеется некоторое расхождение в трактовке источников по истории города у отдельных авторов, а во-вторых, город несколько раз переносился на новое место и разорялся во время нападения. Это связано не только с тем, что отсутствуют специальные монографические работы по истории низовьев Терека, но и с тем, что не проводились археологические раскопки в регионе. Эти факторы породили много версий и весьма спорных предположений. Анализ исследований и публикаций Е.Н. Кушевой [1], В.Б. Виноградова [2], Т.С. Магомадовой [3], Н.Н. Великой [4], С.А. Головановой [5], И.Х. Тхамоковой [6] и др., в которых рассматривались аспекты этой проблемы и на которых основывается автор, позволяет сделать вывод, что тема далека от завершения. Наиболее последовательно вопросы возникновения казачьих городков в Низовьях Терека нашли отражение в работах Е.И. Нарожного [7, c. 28].

Несмотря на то, что некоторая часть исследователей предполагает, что именно как город Терки сформировались в дельте Терека, в связи с отсутствием доказательной базы точное местоположение крепости установить затруднительно [8]. Общеизвестно, что упомянутый г. Терки был поставлен в низовьях Терека еще в 1588 г., на одном из рукавов этой реки. «Этот новый город на реке Тереке, по утверждению еще С. Белокурова, первое время назывался «Терком», и «Терским городом», и «Тюменским новым городом», и «Тюменским острогом» [9, с. 114], что вполне объяснимо [5, с. 253-276]. Однако использование разных по времени и обстоятельствам названий одного и того же пункта, нередко приводит к путанице, каждый раз требуя обязательных разъяснений. Для удобства его принято обозначать Терки-1, Терки-2, Терки-3, Терки-4, Терки-5. В.Б. Виноградов и Т.С. Магомадова [10] подчеркивали, что «по этому вопросу у краеведов (и дореволюционных, и современных) нет единства взглядов», хотя исследователь Е.И. Нарожный справедливо указывает, что при всей привлекательности подобного условного и вполне «удобного» при работе подразделения всех известных объектов, в силу целого ряда объективных причин и обстоятельств такое обозначение городков и острогов, неоднократно переносившихся с одного места на другое, вроде бы демонстрирует их перманентную преемственность. Однако сегодня будет более правильным искать и обосновывать другие, лучше - изначальные (исторические) названия таких объектов. Либо называть их не только «Терками», но и «городками» или «острогами», при этом указывая год строительства [11].

Запутанность вопроса привела к тому, что часть исследователей отождествляет город с одной из крепостей Терки малоизученное Трехстенное городище, часть исследователей считает, что Терки-1 и Терки-2 являлись не чем иным, как Сунженскими острогами и т.Д.

На наш взгляд, следует четко разграничить крепость Терки и Сунженский острог, для чего следует принять версию Е.Н. Кушевой [12, с. 56], что Сун- женский острог, так называемое «старое городище» 1590-1605 г., был построен на месте Терских острогов 1567 и 1578 гг. Довольно часто встречаются работы, авторы которых отождествляют эти крепости. Но, на наш взгляд, это очень спорная версия. Они отличались как по размерам и характеру строения, так и по своему назначению и месторасположению. Терские города - это довольно крупные укрепленные поселения, наподобие тех городов-крепостей, которые возводились на окраинах государства. Сунженские крепости - это небольшие строения, именуемые в источниках «острожками». Предназначались они для охраны «перевозов» через Сунжу и Терек. Они носили временный характер, были форпостами Терского города, постоянных гарнизонов и жителей не имели. Они были построены в период существования Терки-3, кроме того, существуют описания дорог от Терков до Сунженского острога. Поэтому, на наш взгляд, отождествлять эти две крепости не совсем верно.

О происхождении названия Терского города в варианте «Терки», на что справедливо указали Б.Г. Алиев и М.-С.К. Умаханов, объяснял еще А. Олеарий, указывая на то, что один из рукавов Терека «назывался, как и теперь его зовут, Тер(е)ком. Он дал городу, мимо которого течет, наименование Терки» $[9$, с. 63]. Эту версию дополняют и сведения И.Г. Гербера, отметившего: «Со времени царя Ивана Васильевича, река Терек разделяется к своему устью на разные протоки, отчего и произошло имя Терки во множественном числе» [13, с. 10, прим. 1].

Под Терки-1 следует принимать Терский острог 1567 г., который был построен на левом берегу Терека. История возникновения этой крепости связана с политической обстановкой, которая сложилась после присоединения Кабарды к Русскому государству, так как усиление русского влияния на Кавказе вызвало большое недовольство Турции и Крыма. Набеги, вражда за земли с шамхалом вызвали необходимость походов русских воинских отрядов на Северный Кавказ в конце 50-х - начале 60-х гг. XVI в. Кабардинские князья обратились с просьбой поставить крепость в устье Терека. Весной 1567 г. были посланы на Северный Кавказ «для городового дела» воеводы Андрей Бабичев и Петр Протасьев, которые поставили по левому берегу Терека, против впадения в него Сунжи, первую русскую крепость Терки. Основанием для такого предположения современным исследователям служит сообщение в «Книге Большому Чертежу»: «А против устья реки Сунши, на другой стороне Терка, острог» $[14$, с. 90]. В крепости были пушки, пищали, в составе гарнизона были царские ратники-стрельцы и другие служилые люди.

Сооружение крепости вызвало недовольство в Турции и Крыму, которое грозило военными действиями России. Турецкий султан и хан предприняли поход на Астрахань, затем совершили поход на Москву в 1571 г. Иван Грозный приказал срыть крепость Терки, а жителей и войска увести в Астрахань. Турецкий султан и хан продолжали настаивать на отдаче им Казани и Астрахани, и летом 1572 года крымский хан предпринял поход на Москву, но был разбит русскими войсками под руководством воеводы М.И. Воротынского. 
Под Терки-2 следует понимать восстановление прежней крепости в 1578 году, по просьбе кабардинских князей. Посланный из Москвы воевода Лукьян Новосильцев начал ставить крепость «на реке на Тереке усть Сунцы-реки» [12, с. 256]. Через год политическая ситуация снова изменилась. Воевода Новосильцев разбил войско крымского хана, которое возвращалось после поражения в Персии, куда хан шел оказать помощь Турции. Узнав об этом, турецкий султан и хан вновь потребовали у России снести этот город. В период Ливонской войны Иван Грозный принимает решение «оставить город» [15]. Еще не достроенный город оставили, а людей перевели в Астрахань. Но город продолжал существовать после официального упразднения, так как он не был снесен, а вскоре занят вольными терскими казаками. На указание турок уйти казаки ответили отказом, а русское правительство заявляло, что на Тереке живут неподчиняющиеся им «беглые, казаки, воры», хотя оказывало им помощь продовольствием и вооружением.

Под Терки-3 следует принимать крепость, основанную в 1588 г., первоначально располагавшуюся (до 1669 г.) на одном из средних рукавов Терека речке Тюменке (в современный период Старый Терек), примерно в 5 верстах от ее впадения в море. В известных сегодняшней науке источниках имеются две версии основания Терки в дельте Терек: на месте прикаспийского города Тюмень и на противоположном берегу от Тюмени. В первые годы Терскую крепость именовали Тюменский город (следует отличать от Тюменского владения) [16, с. 213].

Крепость имела вид острога, сделанного из дерева и земли. Она была снабжена «нарядом», то есть артиллерией, а ее гарнизон в основном состоял из стрельцов, вооруженных ручным огнестрельным оружием - пищалями. Начало гарнизону и населению Терского города положили полторы тысячи стрелецких семей, переведенных сюда на «вечное житье» из центральных городов страны [17]. Первым воеводой нового Терского города был князь А.И. Хворостин, являвшийся подручным астраханского. В результате наводнения вода затопила город, полностью смыв его восточную стену и причинив другие разрушения, после чего город перенесли на новое место.

Терки-4 был отстроен (1669 г.) неподалеку от оставленной крепости Терки-3, на Копани (это часть участка дельты Терека, сейчас местность условно можно соотнести с Копайским гидроузлом, Кизлярский р-н РД). Редко, но встречалось название новой крепости как «город на Копани».

Из Астрахани было прислано 100 мастеровых по дереву, всеми работами руководил присланный из Москвы крупный «горододелец» (фамилия в источниках не названа). В 1669 году он сооружался по присланному из Москвы чертежу и под руководством московских «горододельцев», которых возглавлял, по сведениям Я. Стрейса, английский полковник Т. Бейли [18]. В течение года на новом месте были построены Малый город и земляной (Большой) город, перетранспортировано население, но в связи с восстанием С. Разина было принято решение Земля- ной город разрушить. Остатки от первого месторасположения этого Земляного города некоторые исследователи предлагают считают Трехстенным городищем, крепостью, которая является «белым пятном на археологической карте Низовий Терека» [19]. Однако в этом вопросе до сих пор нет необходимой ясности. В словаре Брокгауза и Эфрона при характеристике Терки, указано: «на 10-вер. карте Кавказского края значится под именем "быв. креп. Трехвальный городок Терской"» [20, с. 22].

Иногда встречаются мнения, что Терки и Трехстенный городок - это одна и та же крепость. Мы считаем более доказательным мнение Е.И. Крупнова, согласно которому «Трехстенная крепость - это одиночная крепость, входившая в одну из ранних оградительных линий на окраине Московского государства, включавшая валы, сторожевые посты и городки» [21]. Нам кажется убедительным мнение отдельных дореволюционных исследователей, которые принимали эту крепость за город, построенный здесь в конце XVI в. вольными русскими казаками и окруженный «обширным окопом в виде треугольника, почему и назвали трехстенным» [22, с. 13]. По нашему мнению, отождествлять эту крепость с Терки не стоит, так как аналогий Трехстенному городку нет на Северном Кавказе и параллели ему следует продолжать искать не на Кавказе [23].

Заслуживает внимания, на наш взгляд, мнение исследователя Е.И. Нарожного о том, что предложенная Е.И. Крупновым в 1935 году идентификация названия памятника, из источника с крепостью, имевшей 3 вала, хотя и располагавшихся по внешнему периметру подтрапециевидного в плане укрепления, долго не «смущала» никого и поддерживалась вплоть до настоящего времени [24, с. 29 и др.].Таким образом, по мнению Е.И. Нарожного, обнаруженная Е.И. Крупновым крепость - остатки города Терки 1588 г. [5, с. 253-276], по праву рассматривающегося как занимавший «на юге страны по значимости и величине второе место после Астрахани» [25, с. 24].

Однако реальный Трехстенный городок следует искать, как отмечал еще И.А. Гильденштедт, непосредственно у места впадения одного из рукавов Терека в Каспийское море [5, с. 253-276; 6, с. 352-362].

Следует учесть, что казаки называли свои укрепленные поселения «городками», но они не относились к городским поселениям в полном смысле этого слова, так как не имели других важнейших признаков города - развитого ремесленного производства и сколько-нибудь значительной торговли, да и по населению они были не столь уж велики.

В этой связи неубедительна, но интересна одна из альтернативных версий, по которой Терки были основаны волжскими казаками в 1573 г. или же, по мнению историка В.А. Потто, Терский город в дельте Терека якобы был основан гребенскими казаками В подтверждение им приводится старинное предание: «... три атамана донских и волжских казаков, навлекших на себя царскую опалу, в 1579 году совещались в низовье Волги, куда им укрыться от царского гнева. Старший из них, Ермак Тимофеевич, потянул на север...остальное казачество выплыло в море и, разбившись на два товарищества, направи- 
лось к Яику, а большинство - к тому же Тереку, в глухое приволье тюменского владения, где с давнейших пор заведен был разбойничий притон для всех воровских казаков. Там они остановились и построили свой трехстенный городок, названный Терки, куда и стали собирать к себе кабардинцев, чеченцев, кумыков и даже черкесов. Разноплеменная смесь всех этих элементов впоследствии и образовала из себя правильное Терское войско» [22].

Ф.А. Котов, московский купец, отправленный в Персию с товарами из государевой казны, посетив в 1623 году Терки, сообщал: «А на Тереке город деревянный, не велик, только хорош, стоит на низменном месте, над рекою Тюменкою ... от моря верст пять и тою же Тюменкою въезд в море... и около все камыш...» [26, с. 77]. Голландский путешественник XVII века Я. Стрейс сообщал, что Терки располагаются в устье Тюменки на расстоянии «почти часу» езды до моря [16, с. 214]. На это местоположение города указывает «Книга Большому чертежу» [14, c. 92]. С характерной для этого автора восторженностью, Э. Челеби, турецкий путешественник XVII века описывал Терки следующим образом: «... на берегу ... залива Каспийского моря, как белый лебедь, виднелась Терская крепость». И далее сообщал: «... это крупный и наиболее отдаленный порт на границе Дагестана и королевства Москвы. Все московские купцы сходят здесь с кораблей и направляются в Дагестан, Грузию и Иран» [27, с. 104].

В XVII в. Терки становятся важным центром политических и экономических связей России с народами Северо-Восточного Кавказа. В Терках находились не только военно-служилое население - там жили временно или постоянно русские торговые люди, работные люди, обслуживающие приходившие с моря бусы и стружки и рыбные промыслы. Отдаленность Терков от других русских городов, сложность его снабжения и постоянная напряженность [28, с. 94] обстановки в регионе замедляли темпы его роста. Но в период расцвета, до нашествия кубанских «татар» в 1708 году, Терки был оживленным городом с пестрым населением, с посадом и большим гарнизоном. Уже в первой половине XVII века под стенами Терского города, в его заречной части, сложились «слободы великие» [12], занятые северокавказским населением: Черкасская, Окоцкая, Новокрещенская и Татарская. Самой большой была Черкасская слобода. К концу XVII века в ней насчитывалось 175 дворов, а в Окоцкой - 160. В целом же общее число выходцев из среды горских народов Северо-Восточного Кавказа чуть ли не в три раза превосходило число русского населения в городе [29, c. 33]. «При основании города туда было переселено из России 1500 человек, а затем еще 500 человек». В 90-х годах XVI века у города поселились кабардинские князья К. Камбулатов и С. Енгалычев со своими подданными. К 1640 году в основанной ими Черкасской слободе числилось 175 дворов. По соседству с ней возникла Новокрещенная слобода, образованная крестившимися переселенцами из разных районов Северного Кавказа, и Окоцская слобода. 160 семей окочан переселились под Терки в конце XVI века. Имелась под городом и татарская слобода. В момент перенесения города в 1669 году в нерусских слободах Терок насчитывалось более 1000 дворов [28]. Известно также, что в состав городского гарнизона входили тогда 500 местных стрельцов, в добавление к которым ежегодно посылали 500 «годовальщиков» из других городов [28]. Сведений о численности других категорий русского населения Терок нет, но известно, что перенесение построек и строительство новых стен осуществляли все терские жители, среди которых были не только служилые люди и «иноземцы», но и люди «жилецкие» [30].

Административным центром города был Кремль - небольшая, но хорошо укрепленная деревянная крепость. В 1689 году после сильного пожара, уничтожившего множество строений, Кремль пришлось строить заново. Но из грамоты астраханскому воеводе и расписного списка Терок видно, что новые стены были сооружены по «старой черте в вышину в 10 бревен». По четырем углам Кремля возвели четыре глухие башни - Красную, Деловую, Угольную и Малый Раскат, проезжие башни - Троицкую и Никольскую и трое «малых ворот», одни из которых назывались Водяными. В Кремле находились: воеводский двор, окруженный бревенчатым частоколом, с двухэтажными хоромами, избами для челяди и хозяйственными постройками; приказная изба с колодничьей палатой и застенком; пороховой склад; житница; три избы для аманатов; воротные караульни; «соборная церковь» и 149 жилых дворов. По площади Кремль был невелик, и его часто называли просто «Малым городом» [31, с. 44].

К Кремлю примыкала земляная крепость с башнями, называемая Земляным или Большим городом. В 1689 году, когда укрепления пострадали от пожаpa, фашинные стены Большого города восстанавливали, как и Кремль, «по старой черте и округе, на трехстах на двадцати четырех же саженях... в подошве в ширину в пяти сажен, а вверху в ширину три сажен, в вышину четыре сажен». В стенах Большого города были башни: Кузнечная, Окотская, Труба, Пригонная, Степная, Банная, Николаевская и Богородицкая. Кроме того, в состав укреплений входили Большой и Малый Роскаты, рогатки и вырытый с внешней стороны вала ров. Внутрь Земляного города вели ворота: Николаевские, Богородицкие или Пречистинские, Степные, Песчаные и Калиточные. В стенах Земляного города располагались жилые слободы, базар с торговыми рядами, гостиные дворы, харчевни, отдельные лавки и две приходские церкви. Из административных зданий там находились таможня, кружечный двор, торговая баня и полковые избы. На одной из городских башен были даже часы с курантами, что в те времена было чрезвычайной редкостью [27, с. 104].

По своей величине и значимости на юго-востоке Русского государства Терки в XVII веке занимал второе место после Астрахани. В военно-административном и финансовом отношении Терки был подчинен Астрахани и по этим же вопросам в Москве приказу Казанского дворца. По всем вопросам внешних сношений Терский городок, как пограничный, был непосредственно связан с Посольским приказом, где каждый год откладывался так называемый «Тер- 
ский столбец». Дипломатическую миссию выполнял воевода с небольшой группой людей, в которую входили дьяки, подьячие и толмачи-переводчики. Все посольства, ехавшие из Русского государства в Персию и закавказские государства, а также из СевероВосточного Кавказа в Москву, как правило, останавливались в Терском городе [33, с. 331].

В XVII веке Терки - крупный торговый центр, где шла бойкая торговля между русскими, северокавказскими, закавказскими и восточными купцами. В городе, кроме официальных зданий, имелись торговые ряды, гостиные дворы (Старый, Новый и Гилянский), где останавливались русские и другие купцы. По сведениям Эвлия Челеби, здесь было 9000 каменных строений, 70 церквей, 3000 лавок и 10 постоялых дворов [27, с. 71]. Город был многолюдным и разноязыким. Ближайшая округа была довольно оживленной, у города располагались огороды, виноградники, поливные пашни. За ними находились загородные усадьбы кабардинских князей и Богоявленский(Благовещенский) мужской монастырь, основанный в 70-х годах XVII века. В базарные дни в Терский город привозили свои товары кабардинцы, кумыки и горцы Дагестана, а также гребенские казаки, пригонявшие лошадей и скот на продажу [34, c. 41].

Ближайшие соседи - представители народов Северо-Восточного Кавказа - доставляли сюда хлеб, просо, ячмень, мед, овчины, попоны, марену, шубы бараньи и другую горскую одежду. Дагестанцы, кроме того, привозили яблоки, орехи и другие фрукты. Ногайцы доставляли скот и продукты скотоводства. Гребенцы привозили на продажу виноградное вино, фрукты, марену, холст домашнего производства; терские низовые казаки - рыбу и продукты рыболовства, балык, рыбий клей, тюленьи шкуры, тюлений жир и прочее [32, с. 67]. Примерно в пяти верстах от города при впадении Тюменки в море была устроена пристань, у которой причаливали для разгрузки и погрузки морские суда, поскольку из-за мелководья в Тюменке они не могли подходить к самому городу. Сообщение города с гаванью производилось на лодках по реке Тюменке, а также по грунтовой дороге. Малые суда причаливали обычно в ближайшем Баклаковском устье, а более крупные - у главного устья Терека. Там разгружались товары, а также присылавшееся из Астрахани военное снаряжение, разные припасы и хлеб на жалование служилым людям. Для этих припасов и товаров было выстроено несколько государственных и частных амбаров. На взморье строили и морские суда. По побережью и у острова Чечень низовые казаки, кумыки и другие ловили рыбу и устраивали временные станы [35, с. 463]

Терки был хорошо укреплен и представлял по тем временам довольно сильную крепость. Здесь была сосредоточена вся русская военная сила на Кавказе, не считая терско-гребенских казаков. В середине XVII века его крепостная артиллерия насчитывала 39 больших и малых пушек. Постоянный гарнизон Терской крепости в XVII веке состоял из 2000 воинских людей, хотя из-за тяжелых условий и высокой смертности фактическая численность терского гарнизона, как правило, была меньше штатной. Но ко- гда этого требовали обстоятельства, в Терки присылались стрельцы-годовальщики из Астрахани и других городов. Так, в 1637 году в составе гарнизона Терской крепости насчитывалось: детей боярских 41 человек, конных стрельцов - 347, пеших стрельцов и годовых казаков - 624, годовальщиков - 500, а всего 1512 человек [36, с. 47]. Общее начальствование над войсками принадлежало терским воеводам, являвшимся главными представителями царской власти на Тереке и соединившим в своих руках гражданское и военное управление. В состав Терского гарнизона входил также конный отряд, выставляемый жителями нерусских слобод Терков. Численность этого отряда иногда доходила до 500 человек. Командовал ими кабардинский князь Сунчалей Янглычевич, позже - его потомки. Население зареченских слобод, как правило, находилось на военной, дипломатической и прочей административной службе у Русского государства (переводчики, послы, проводники). Естественно, в таком многолюдном и разноплеменном сообществе, как Терский город, происходил живейший культурный обмен, знаниями и идеями.

Низовые казаки жили разбросанными юртами в Терском заболоченном приустье, держались сплоченными ватагами. Численная сила их войска постоянно колебалась, так как в любое время «какая-то часть казаков могла морем уйти на Волгу». Наиболее устойчивыми были семейные казаки, жившие пригородными слободами по берегам Терека. Оседлые казаки получали жалование, когда привлекались к проведению какой-либо военной акции [37]. Что касается нерусского этнического элемента, входившего в состав Терско-низовой казачьей вольницы, который В.А. Потто называл презрительно «разнокалиберный сброд» [22] - это были выходцы из местных кавказских народов. Особый интерес представляет группа так называемых «новокрещенов», выделившаяся из кавказских горцев и принявшая православие. Позже новокрещены входили как особый служилый разряд в состав Терско-низового войска. С появлением Терской крепости Россия принимала все меры, чтобы установить свой контроль над проходящими через Дагестан военно-стратегическими и торговыми путями.

За время своего существования Терский город пережил много разных бед и несчастий. Так как город и крепость были деревянными, легко воспламеняющимися, пожары были весьма частым явлением и город не один раз почти полностью уничтожался огнем. Так, пожар 1639 года уничтожил гостиные дворы, торговые лавки, склады, многие дома. В 1660 году в Терском городе вспыхнула эпидемия чумы, занесенная с Востока. Она произвела такое опустошение, что царь повелел астраханским воеводам направить на Терек присланных из Симбирска 1379 стрельцов и городовых казаков с их семьями, которые и были поселены в Терском городе. В 1668 году из-за повышения уровня Каспийского моря вода затопила город, в 1688 году произошел сильный пожар, и в городе сгорело «все без остатку», в 1703 году - наводнение, в 1705 году - землетрясение. Кроме стихийных бедствий город не раз подвергался нападениям вассалов турецкого султана и персидского шаха. В 1643 г. Терки подвергался нападе- 
нию вассала персидского шаха беглербекаширванского Харасу-хана, в 1653 г. шамхал Тарковский напал на Сунженский острог, чтобы потом идти на Терский город. В этом нападении участвовали персидские воины. В результате последнего нападения весной 1708 года отрядов крымских и кубанских татар (иногда называли так ногайцев Малой Орды) и спровоцированной ими части горцев от города остались лишь одни развалины да куча пепла [38].

Город был восстановлен на новом месте, в 7 верстах от впадения реки Быстрой (рукава Терека) в Аграханский залив. Но с этого времени начался период упадка города. Это нашло отражение в сокращении его населения и уменьшении его торгового значения.

Именно в таком состоянии застал Терский город Петр I, с именем которого связан новый этап в истории Дагестана. К началу 20-х гг. XVIII в. от прежнего многолюдства города оставалось не более одной трети. И хотя в военном отношении город Терки-5 представлял еще сильную крепость, все самое славное и героическое у него уже было позади. На всей его жизни лежала печать упадка и запустения. В июле 1722 г. Петр I осмотрел крепость, проверил состояние воинского гарнизона. Расположение города, «ему не понравилось, по низкому и нездоровому месту, а особливо, что укрепление оного потопляемо бывает морскою прибылою водою, а также и из озер полою водою» $[39$, с. 20]. Петр приказал Терский город уничтожить и создать на более удобном месте новую крепость, что и было выполнено. Вместо упраздненной крепости вблизи ее был создан Терский редут с гарнизоном в 150 чел., с одной мортирой и двенадцатью пушками. Однако официально уничтоженный в 1722 г. Терский город просуществовал еще несколько лет. В 1726 г., в результате трансгрессии Каспийского моря, город, называвшийся теперь Терским редутом, подвергся затоплению. После наводнения основная часть его населения была переведена во вновь основанную на Северном Кавказе крепость св. Креста на р. Сулак, а Терский редут сохранили только как чисто военное укрепление. После 1728 г. в документах он уже не упоминается [40].

За сравнительно короткое время своего существования (официально с 1588 по 1725 г., около 140 лет) Терский город выполнил свою историческую миссию в качестве южного форпоста российской государственности, проводника ее кавказской политики на Северо-Восточном Кавказе.

\section{СПИСОК ЛИТЕРАТУРЫ:}

1. Кушева Е.Н. О местах первоначального расселения гребенских казаков // Историческая география России XVIII в. Ч.П. Источники и их характеристика. М., 1981. С. 78-83.

2. Виноградов В.Б., Магомадова Т.С. О месте первоначального расселения гребенских казаков // Coветская этнография. М., 1972. № 3. С. 31-42.

3. Магомадова Т.С. Первые русские крепости в междуречье Терека и Сунжи в XVI-XVII вв. // Вестник АН ЧР. Грозный, 2010. № 2 (13). С. 106-113.

4. Великая Н.Н. Терское казачество в XVIII - первой трети XIX в.: Очерки истории и культуры казачества Юга России / под ред. Г.Г. Матюшова,
И.О. Тюменцева. Волгоград: ЮНЦ РАН, Волгоградский филиал ФГБОУ ВПО «РАНХГС РФ», 2014. $624 \mathrm{c}$.

5. Голованова С.А., Нарожный Е.И. Городище «Трехстенный городок» (XIII в. - 1668 г.) // МИА Северного Кавказа. Вып. 5 / под ред. Е.И. Нарожного. Армавир: РИЦ АГПУ, 2005. С. 253-276.

6. Тхамокова И.Х. «Трехстенный городок» и его место в истории Северного Кавказа // Научный диалог. Екатеринбург. 2015. № 12 (48). С. 352-362.

7. Нарожный Е.И. К исторической географии низовьев Терека // Пути возрождения терского казачества: тез. докладов региональной конф. Кизляр: ККМ, 1993. С. 7-8.

8. Магомадова Т.С., Виноградов В.Б. О месте первоначального расселения гребенских казаков // Coветская этнография. М., 1972. № 3. С. 31-43.

9. Алиев Б.Г., Умаханов М.-С.К. Историческая география Дагестана (XVII - нач. XIX в.). Кн. 1. Махачкала: Изд-во ДНЦ РАН, 1999. 180 с.

10. Виноградов В.Б., Магомадова Т.С. Где стояли Сунженские городки // Вопросы истории. 1972. № 7. C. 205-208.

11. Нарожный Е.И. Историко-географические реалии Нижнего Поволжья и Терско-Сулакского междуречья рукописной карты 1720-х гг. // APRIORI. Серия: Гуманитарные науки. 2016. № 5. С. 1-29.

12. Кушева Е.Н. Народы Северного Кавказа и их связи с Россией в XVI-XVII вв. М.: Издательство Академии наук СССР. 1963. 371 с.

13. Известие о находящихся с западной стороны Каспийского моря, между Астраханью и рекой Куром народах и землях и о их состоянии в 1728 году, сочиненное полковником артиллерии И.Г. Гербером // Сочинения и переводы к увеселению и пользе служащих. СПб.: Императорская Академия наук, 1760.

14. Книга Большому Чертежу /под ред. К.Н. Сербиной. М.-Л.: Издательство АН СССР. 1950. 248 с.

15. РГАДА. Ф. 371. Д. 458. Л. 202 об.

16. Стрейс Я.Л. Три путешествия / пер. Э. Бородиной; ред. А. Морозова. М.: ОГИЗ, 1935. 415 с.

17. Гарунова Н.Н. Русские города Притеречья в кавказской политике России 18-19 вв. // Сборник статей и докладов науч.-практ. конф. университетов Юга России, посв. 270-летию города Кизляра. 2005. С. $149-156$.

18. Энциклопедический словарь Брокгауза и Ефрона в 86 т. (82 т. и 4 доп.). СПб., 1890-1907.

19. Крупнов Е.И. Городище «Трехстенный городок» // Советская археология. 1935. № 2. С. 118-124.

20. Потто В.А. Два века терского казачества. Ставрополь, $1991.256 \mathrm{c}$.

21. Крупнов Е.И. Трехстенный городок // Советская этнография. М., 1935. № 3. С. 34-38.

22. Потто В.А. Кавказская война: В 5 т. Т. 1. С древнейших времен до Ермолова. Ставрополь: Кавказский край, 1994. 96 с.

23. Garunova N.N. «Tryokhstennyi Gorodok» in the Context of the History of Lower Reaches of the Terek till XVIII Century // Былые годы. Российский исторический журнал. Sochi: Sochi State University. 2015. V. 35. Is. 1. P. 48-54.

24. Гаджиев В.Г. Сочинение И. Гербера «Описание стран и народов между Астраханью и рекою Ку- 
рой находящихся» как исторический источник по истории народов Кавказа. М.: Наука, 1979. 271 с.

25. Суздальцева И.А. Внешний облик, социальная организация и население Терского города в XVII нач. XVIII в. // Известия Дагестанского государственного педагогического университета. Общественные и гуманитарные науки. Махачкала, 2008. № 4. C. $24-30$.

26. Котов Ф.А. Хождение купца Котова в Персию. М., 1958.97 с.

27. Эвлия Челеби. Книга путешествия (Извлечения из сочинения турецкого путешественника XVII века) / Пер. и коммент. М., 1979. Вып. 2. 200 с.

28. Кабардино-русские отношения в XVI-XVIII вв.: документы и материалы: в 2-х т. / сост.: Н.Ф. Демидова, Е.Н. Кушева, А.М. Персов; ред.: Т.Х. Кумыков, Е.Н. Кушева. М.: Издательство АН СССР, 1957. Т. І. XVI-XVII вв. 479 с.

29. Голикова Н.Б. Очерки по истории городов России конца XVII - начала XVIII в. М.: Изд-во МГУ, 1982. $216 \mathrm{c.}$

30. ЦГАДА. Ф. 199. Портфель Миллера. П. 150. Ч. 15. Д. 22. Л. 6.

31. Васильев Д.С. Очерки истории Низовий Терека (досоветский период). Махачкала: Даг. кн. изд-во, $1986.260 \mathrm{c}$

32. Гриценко Н.П. Истоки дружбы (из истории экономических, культурных связей и дружбы чеченского, ингушского народов с великим русским народом и народами Кавказа). Грозный: Чечено-Ингушское книжное издательство, 1975. 196 с.
33. История народов Северного Кавказа с древнейших времен до конца XVIII века. T. 1. М.: Наука, 1988.554 с.

34. Гарунова Н.Н. Казачьи городки и крепости в Низовьях Терека в XVII-XVIII вв: мифы и реальность. Махачкала, 2016. 164 с.

35. Попко И.Д. Терские казаки со стародавних времен. СПб., 1880. С. VIII. 600 с.

36. Гриценко Н.П. Города Северо-Восточного Кавказа и производительные силы края. V - 1 пол. XIX века. Ростов-на-Дону, 1984. 159 с.

37. Иноземцева Е.И. Казачество России в контексте крупномасштабной внешнеполитической акции Низового корпуса императорских войск в ЮгоЗападном Прикаспии (1722-1735 гг.) // Вестник Института истории, археологии и этнографии. 2016 № 2 (46). С. 13-19.

38. Гарунова Н.Н. Терский город и крепость Святого Креста - опорные пункты кавказской политики России XVI - 1 пол. XVIII в. // Памятники фортификации: история, реставрация, использование: сб. статей и мат-лов Первой междунар. науч.-практ. конф. Архангельск, 2012. С. 218-225.

39. Бутков П.Г. Материалы для новой истории Кавказа с 1722 по 1803 год. Ч. 1. СПб., 1869. 649 с.

40. Гарунова Н.Н. Описание кордонных постов, станиц и крепостей Кавказской линии укреплений по неопубликованной рукописи И.Ф. Бларамберга (первая половина XIX в.) // Вестник Дагестанского государственного университета. Серия 2: Гуманитарные науки. 2015. № 4. С. 32-38.

\section{«TEREK STOCKADED TOWN, TEREK REDOUBT, TERKI? ...» (THE ROLE OF TEREK IN THE HISTORY OF THE NORTH-EASTERN CAUCASUS IN THE XVI-XVII CENTURIES)}

Garunova Nina Nurmagomedovna, doctor of historical sciences, professor of Department of History from the Earliest Times to the End of XIX Centuries

Dagestan State University (Makhachkala, Russian Federation)

Suzdaltseva Irina Anatolievna, candidate of historical sciences, associate professor of History of Russia Department Dagestan State Pedagogical University (Makhachkala, Russian Federation)

Galimova Lilia Nadipovna, doctor of historical sciences, professor of Humanities and Social Studies Department Ulyanovsk Institute of Civil Aviation named after Chief Marshal of Aviation B.P. Bugaev (Ulyanovsk, Russian Federation)

Abstract. This article examines the history of the disappeared Russian settlement-fortress, which refers to the period XVI-XVIII centuries. In earlier sources the city was called the redoubt of the Terek, the Terek fortress, sometimes there is a shorter name - Grater. Later they began to use the name Terek the city, represents the city and fortress near the mouth of the Terek, not far from the now not-existing of the river Tyumenka. In the modern period is the territory of the left Bank of the Old Terek to the North-East of the city of Kizlyar, Republic of Dagestan.

Criticized the attempts to identify the history of the two fortresses: Walled town and Floats, as well as their role at the initial stage in the formation of Russian population of Dagestan. Characterized by the influence of the process of renewal of the Cossacks in military servicemen estate on the historical development of areas North-Eastern Caucasus. Attention is paid to issues such as the existence of different versions of the city name, the location where divergent opinions of researchers.

Emphasis is placed on the role of the Terek city as the southern Outpost of the Russian state, the conductor's Caucasus policy on the North-Eastern Caucasus.

The analysis of the problem, which allowed us to consider the integration of the provincial regions in the periphery of the Russian state in the South of the country, and analyzed the development of reference points to spread the influence of Russia in the XVI-XVII centuries.

Keywords: fortress; settlement; Float; Terek the city; jail Terek Cossacks; politics; Russia; North-Eastern Caucasus; trade; the Governor; the merchants of the Kremlin; border; Sloboda; redoubt; Ostrog; estuary of Terek; artillery; garrison; flooding; shopping arcade; tower; courtyard; service people; vehicle; weapons. 